UC-70

LA- -9058-1.1S

DE82 010977

\title{
Removal of Contaminated Air Scrubbers \\ at TA-35-7, \\ Los Alamos National Laboratory
}

Johnny R. Harper

Raymond Garde

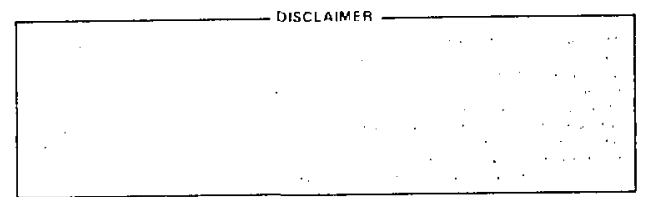




\title{
REMOVAL OF CONTAMINATED AIR SCRUBBERS AT TA-35-7, LOS ALAMOS NATIONAL LABORATORY
}

\author{
by
}

Johnny R. Harper and Raymond Garde

\begin{abstract}
Five large excess contaminated air scrubbers located in Building 7 at TA-35 were removed and disposed of in 1979-1980. The scrubbers were contaminated with strontium-yttrium and cesium. This report details the removal procedures, the health physics program, the waste management program, and the costs of the operation.
\end{abstract}

\section{INTRODUCTION}

Five large air scrubbers located at Technical Area (TA)-35 of the Los Alamos National Laboratory, Los Alamos, New Mexico, became obsolete following filtration modifications in 1954. The scrubbers (Fig. 1) were constructed in the mid 1940s in structure TA-35-7 to receive contaminated exhaust air from laboratory building TA-35-2. They were contaminated with strontium-yttrium $\left({ }^{90} \mathrm{Sr}-\mathrm{Y}\right)$, cesium $\left({ }^{137} \mathrm{Cs}\right)$, and low levels of transuranics.

Removal of the scrubbers was required because of their deteriorating condition and because the building offered $600 \mathrm{~m}^{2}$ of floor space for other laboratory needs (Fig. 2).

II. DESCRIPTION OF THE SCRUBBER SYSTEM

The exhaust system was designed to collect contaminated exhaust air and liquid wastes from laboratory building TA-35-2. The air and liquid wastes were separated in a structure designated as TA-35-3, the Phase Separator Pit. The 
liquids flowed to TA-35-10, the holding tanks, while air ducts carried the exhaust air from TA-35-3 into the five scrubber systems and stacks at TA-35-7.

Planning for the scrubber removal began in mid 1979. As-built drawings wer obtained and preliminary radiation surveys were performed. The internal surveys indicated a maximum of $100 \mathrm{mR} / \mathrm{h}$ beta activity and about $10^{4} \mathrm{dis} / \mathrm{s} / \mathrm{cm}^{2}$ alpha activity on surfaces. A maximum of $200 \mathrm{mR} / \mathrm{h}$ beta activity was fixed into the concrete floor under the scrubber units. No measurable external alpha contamination was encountered. The maximum beta activity found in the 15 existing floor drains was $80 \mathrm{mR} / \mathrm{h}$; the average was $22 \mathrm{mR} / \mathrm{h}$.

Four of the five scrubbers designated as FE-12, FE-13,FE-14, and FE-15 were $80 \mathrm{~m}^{3}$ in volume. Each weighed approximately 14.5 metric tons. The maximum estimated activity was $1.9 \times 10^{-2} \mathrm{Ci}{ }^{90} \mathrm{Sr}-\mathrm{Y}$ in scrubber $\mathrm{FE}-15$. The average activity in scrubbers $\mathrm{FE}-12, \mathrm{FE}-13$, and $\mathrm{FE}-14$ was $8.6 \times 10^{-3} \mathrm{Ci}$. The central scrubber dasignated as $\mathrm{FE}-11$ was $100 \mathrm{~m}^{3}$ in volume, weighed 16.3 metric tons, and contained an estimated activity of $6.6 \times 10^{-4} \mathrm{Ci} 90_{\mathrm{Sr}-\mathrm{Y}}$ (Fig. 3).

The scrubbers were mounted on rails and were interconnected by a network of copper pipes (Fig. 4) ranging in diameter from 0.6 to $13 \mathrm{~cm}$. Each scrubber had valved drainage pipes running to two of the three floor drains located under each scrubber.

\section{REMOVAL PROCEDURES}

The removal of the scrubbers began in August using conventional pipe cutters to remove interconnecting piping. Most of the pipes were dry, but one pipe contained about $0.04 \mathrm{~m}^{3}$ of wet sludge, which was collected and taken to the Radioactive Liquid Waste Treatment Facility for treatment. The sludge contained $2 \mathrm{Ci}{ }^{90} \mathrm{Sr}-\mathrm{Y}$ and $2 \mathrm{nCi}{ }^{241}$ Am per gram of sludge. Metal or PVC caps filled with silastic were used to seal the cut pipes. A coating of roofing tar (Fig. 5) was applied over the caps and allowed to harden. Tar undercoating was sprayed over various contaminated areas to $f i x$ potentially loose contamination (Fig. 6). Maximum activity levels encountered were $80 \mathrm{mR} / \mathrm{h}$ beta and $4 \times 10^{3} \mathrm{dis} / \mathrm{s} / \mathrm{cm}^{2}$ al pha.

The FE-15 and FE-13 scrubbers were stripped of pipes and their associated stacks (Fig. 7) and blowers (Fig. 8) were removed. Every scrubber was constructed of six sections (Fig. 9) that were pinned together. The sections 
were supported by wheeled carts sited on the ralls. The scrubbers were separated into $40 \mathrm{~m}^{3}$ halves by unpinning one of the sections and pulling (rolling) the halves apart with a forklift (Fig. 9). The openings were sealed with sheet metal and roofing tar (Fig. 10). The pins of the sections not separated wer: welded secure and the sections were welded onto their wheeled carts. The scrubber halves were removed with a forklift and chained onto a lowboy (Fig. 11). Except for the FE-15 stack and blower, which would be reused, everything else was transported to the Radioactive Waste Disposal/Storage Site $(\mathrm{TA}-54), 8 \mathrm{~km}$ from TA-35-7 (Fig. 12).

A section of the floor next to the FE-15 air duct was scarified free of contamination (Fig. $13 \& 14$ ). A concrete pad was poured on the area to receive the relocated FE-15 blower and stack. This system was needed to satisfy present ventilation requirements for the site.

The FE-12 and FE-14 scrubbers, blowers, and stacks were removed, packaged as previously mentioned, and transported to TA-54.

of the 12 rails in TA-35-7, 10 were contaminated to a maximum level of $20 \mathrm{mR} / \mathrm{h}$ beta at contact. A concrete saw was used to cut them free of the concrete floor (Fig. 15). A jackhammer and water (for dust control) were used (Fig. 16) to free each rail for removal and transport to TA-54.

The drains were filled with an asphalt latex mixture ${ }^{1}$ and covered with a 0.6-cm-thick layer of steel. The contamination remaining in the concrete floor was documented and the floor was capped with a 10- to 15-am layer of uncontaminated concrete (Fig. 17). Resurveys of the new floor indicated background levels to be $\leq 0.05 \mathrm{mR} / \mathrm{h}$ as determined by an unshielded GiegerMueller (GM) probe.

\section{HEALTH PHYSICS}

Personnel assigned to the project were experienced radiation workers. Decomissioning work was not permitted without the presence of a health physics surveyor.

Workers were provided protective (anticontamination) clothing for all work performed; this consistec of underwear, coveralls, gloves, hoods, and booties. No personal decontamination jeyond normal showering and washing procedures was required. All workers participated in a full-face respirator fitting, testing, 
and training program. Full-face respirators equipped with high-efficiency particulate filters were the standard respiratory protestion during phases of decommissioning involving a potential for alrborne contamination. Nose swipes were collected from each worker after every risk period. Analyses of these swipes indicated no inhalation problem had occurred.

Air in the working areas was sampled by passing it through a HV-7O filter paper at a rate of $0.06 \mathrm{~m}^{3} / \mathrm{min}$. The papers were removed at the end of each workday and measured for alpha and beta-gamma activity to provide a record of the workers' potential exposure to airborne contamination. The levels fluctuated from day to day depending upon the work being performed zii never exceeded maximum permissible limits.

All personnel working on the project were provided with monthly beta-gamma dosimeters to record accumulated radiation exposures. The average individual dose for the 10 most active workers was 65 total millirem and was accumulated during the 10 months of work. The highest accumulated exposure was 170 millirem.

A variety of instrumentation was used. A Ludlum-139 an an Eberline PAC 7 with $50 \mathrm{~cm}^{2}$ surface probes were used to determine the presence of alpha activity. A Ludlum-14C with a GM probe was used to measure beta-gamma activity. An Eberline Alpha 3 and a Nuclear Measurements Corporation Windjammer were used as continuous air monitors to provide instantaneous al pha and beta alarms.

\section{WASTE MANAGEMENT}

All wastes generated by this operation were buried at the Laboratory's Radioactive Waste Disposal/Storage Site (TA-54). Burial was in pits, which when full are covered with a meter of uncontaminated soil and revegetated with native plants. About $700 \mathrm{~m}^{3}$ of debris were disposed of.

Most wastes were transported to the disposal site in tarpaulin-covered, plastic-lined dump or flatbed trucks. The scrubber halves were transported on lowboy flatbed trucks. Trucks, loaders, and bulldozers used to load or transport contaminated materials were routinely monitored during the job and decontaminated as necessary. Washing with water was sufficient to remove the contamination. 


\section{ENVIRONMENTAL SUR VEILLANCE}

The Laboratory's Environmental Surveillance Group monitored the operation with its routine air-sampling network ${ }^{2}$ and two additional stations adjacent to the building. Filter papers from the 27 sample locations were collected weekly and analyzed after a 7- to 10-day decay period. No measurable elevation of the gross al pha or beta-gamma activity for Laboratory operations was detected during the period of decommissioning.

VII. $\operatorname{cosTS}$

The project required 180 working days and $\$ 260,000$ to complete. Subcontractor operational manpower and equipment costs were $\$ 200,000$, and Laboratory costs for management and health physics protection were $\$ 60,000$.

\section{REFERENCES}

1. D. C. Nelson and J. L. West, "Contamination Control Demonstration for Radioactive Pipeline Decommissioning," Los Alamos Scientific Laboratory document submitted to the Department of Energy, LA-UR-80-1210 (April 1980).

2. Environmental Surveillance Group, "Environmental Survelllance at Los Alamos During 1979," Los Alamos Scientific Laboratory report LA-8200-ENV (April 1980). 


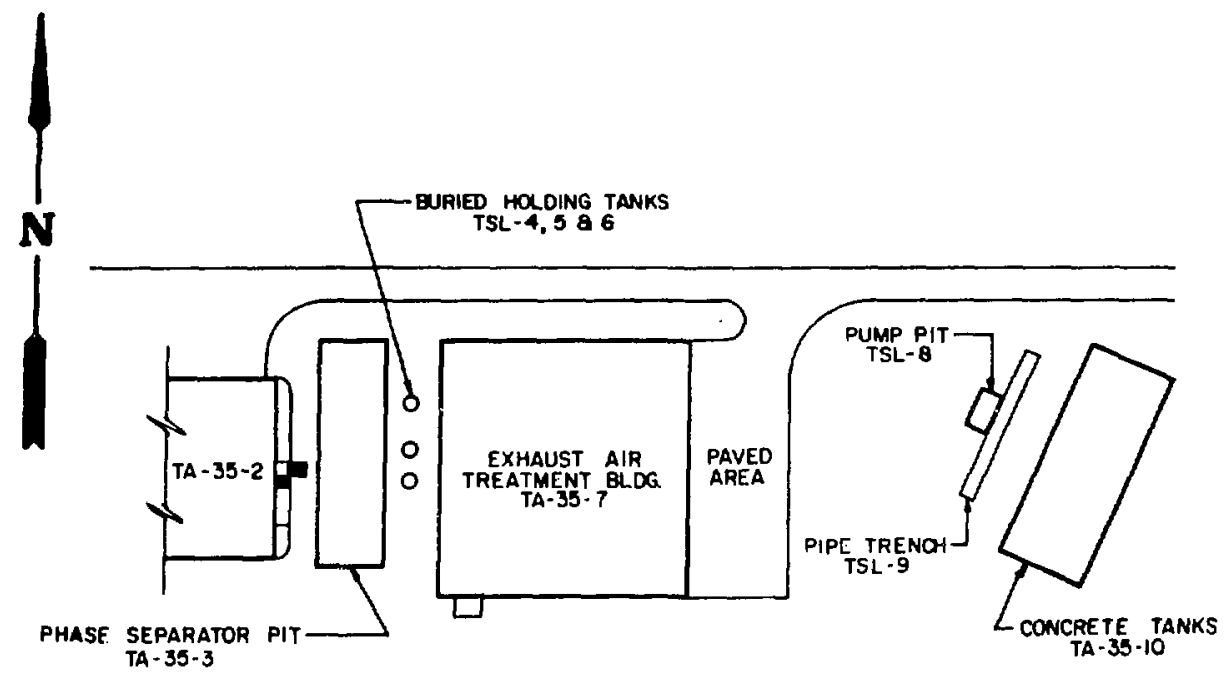

Fig. 1.

Air scrubbers were located in Exhaust Air Treatment Building.

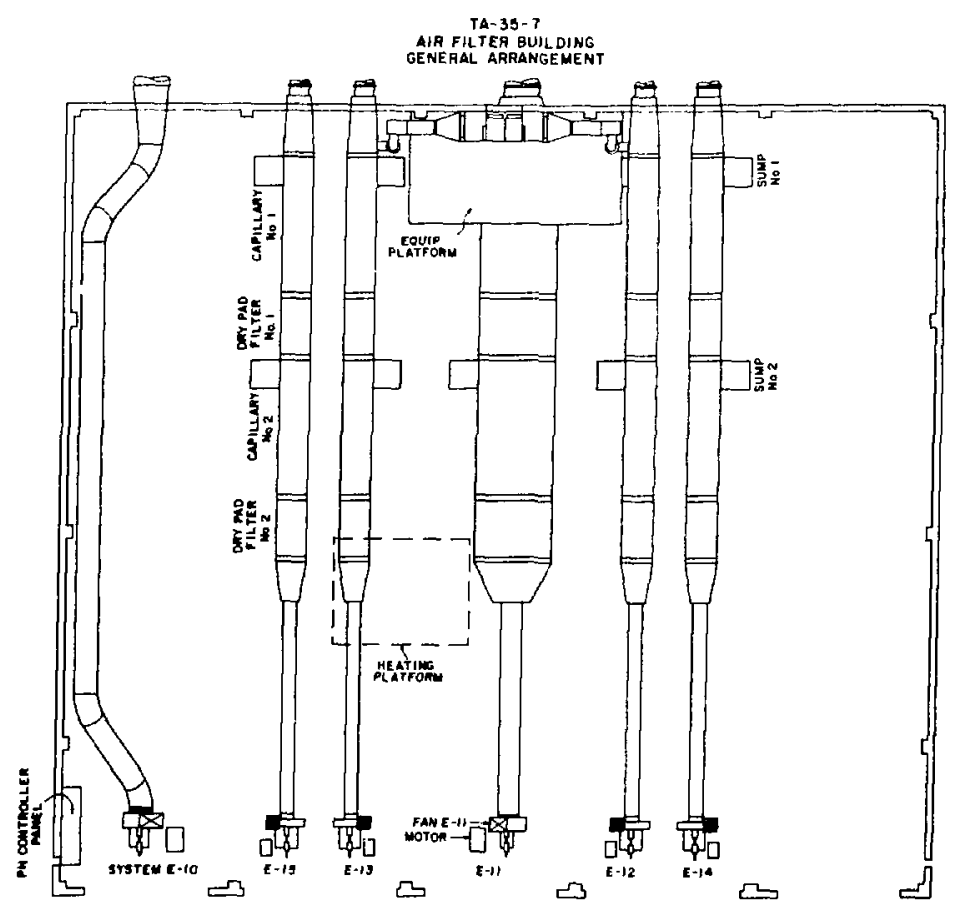

$\mathrm{F} \perp \mathrm{g}$. 2 .

Schematic of scrubbers inside TA-35-7. Bullding dimensions are $28 \mathrm{~m} \times 29 \mathrm{~m}$. 


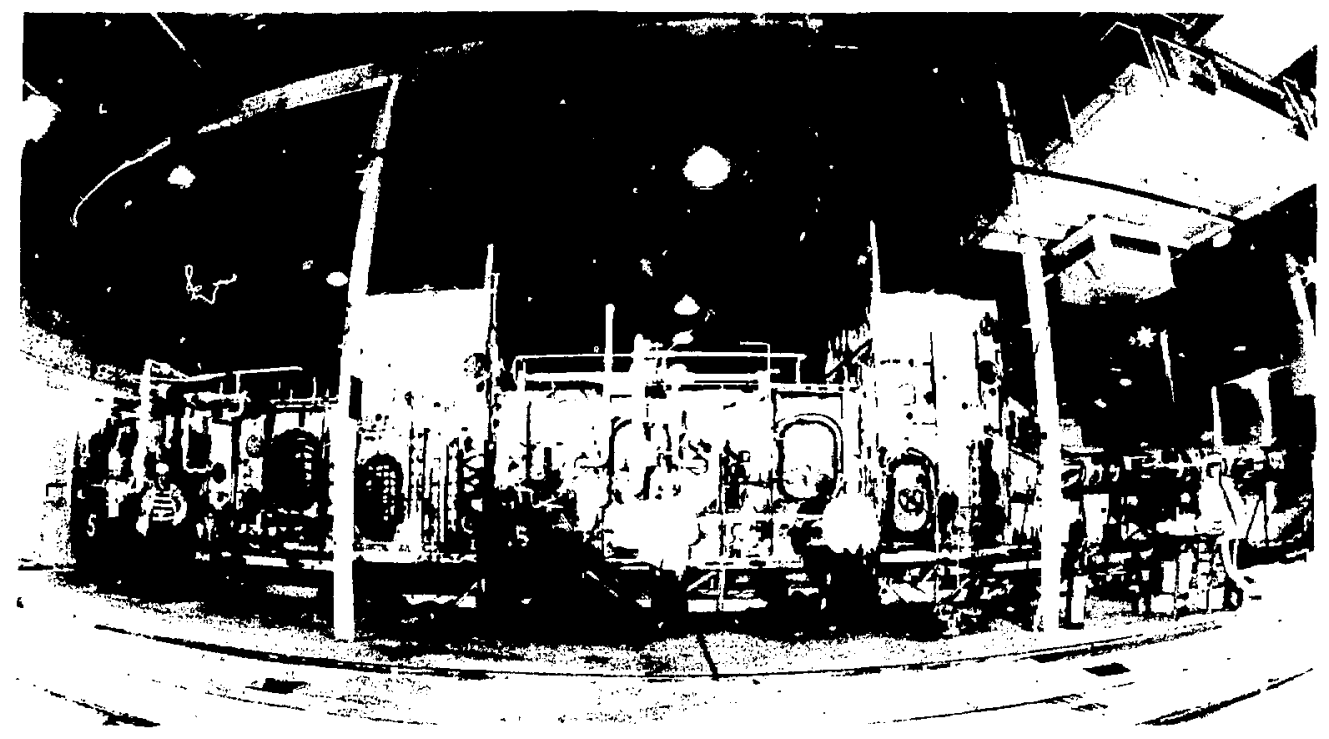

Fig. 3.

A "fish-eye" view of scrubber FE-11. The length of the unit is $25 \mathrm{~m}$.

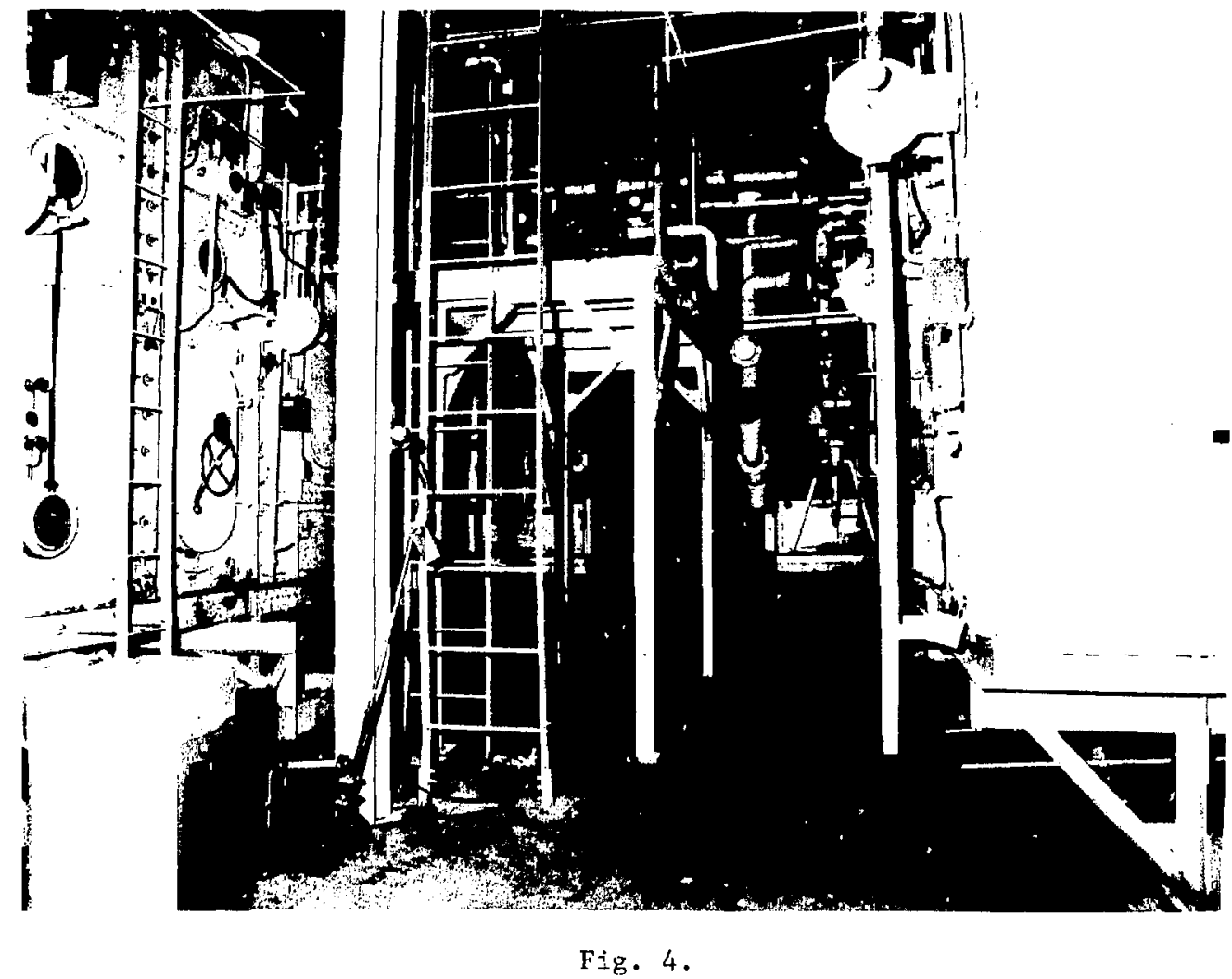

Typical piping between scrubbers. 


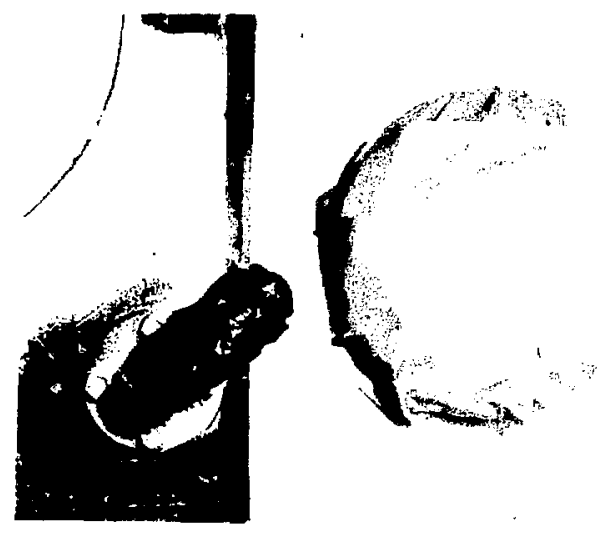

Fig. 5 .

Undercoating tar was used over metal or polyvinylchloride caps.

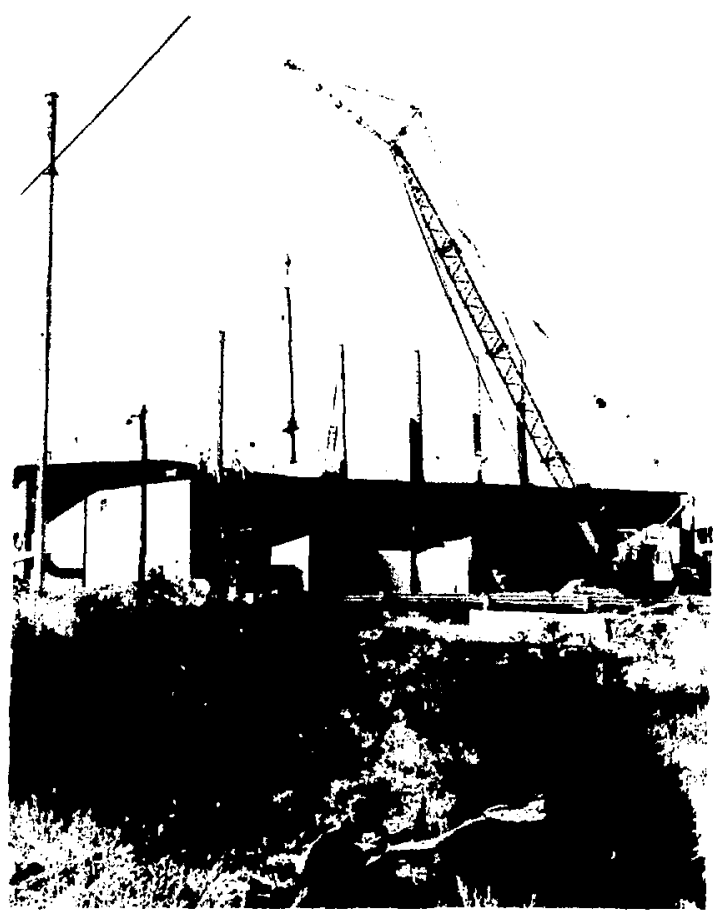

Fig. 7.

Stack removal operation.

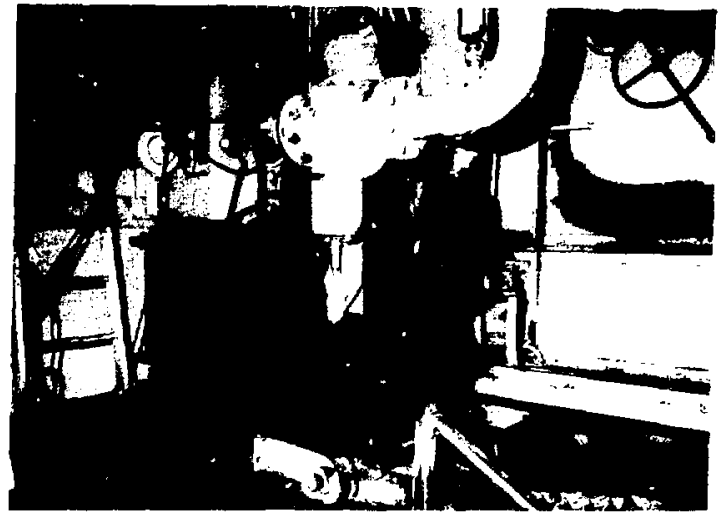

Fig. 6.

Undercoating tar was used to "fix" potentially loose contamination.

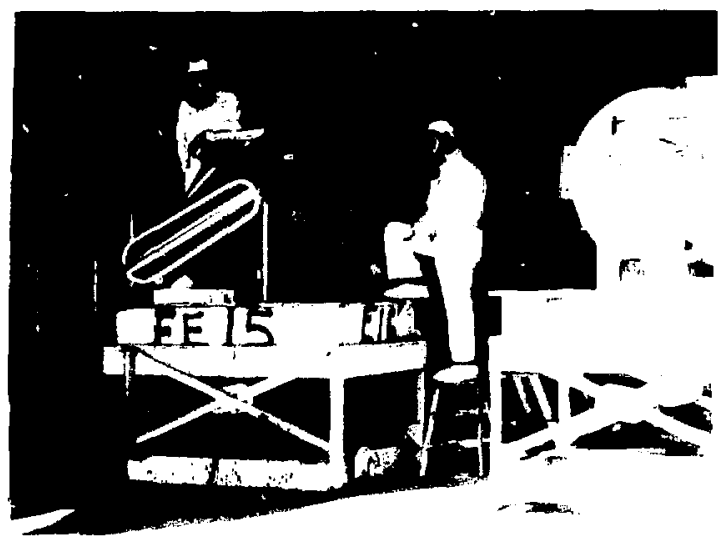

Fig. 8.

Blower ready to be pulled away from scrubber. 


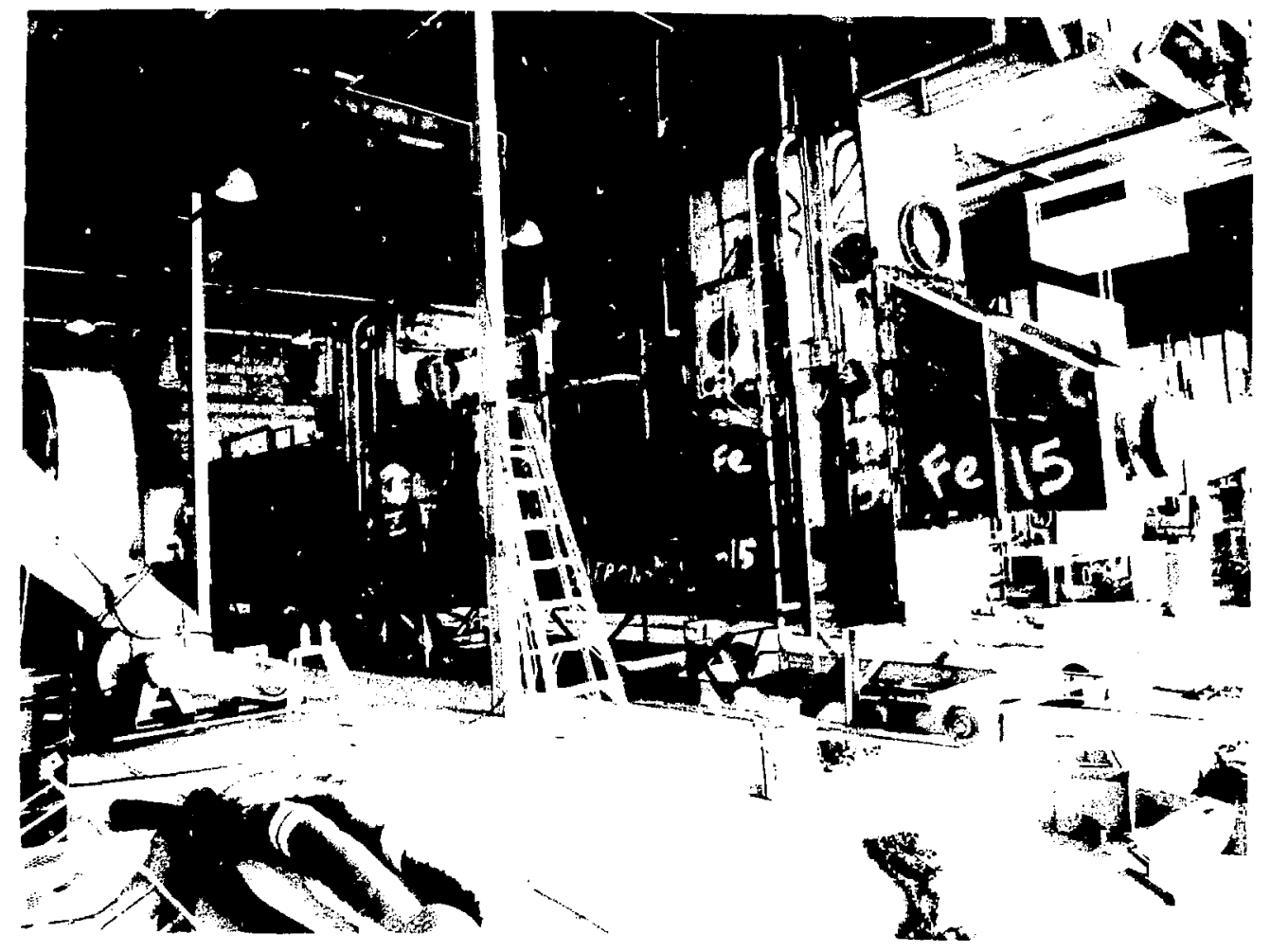

Fig. 9.

Scrubber ready for separation into halves.

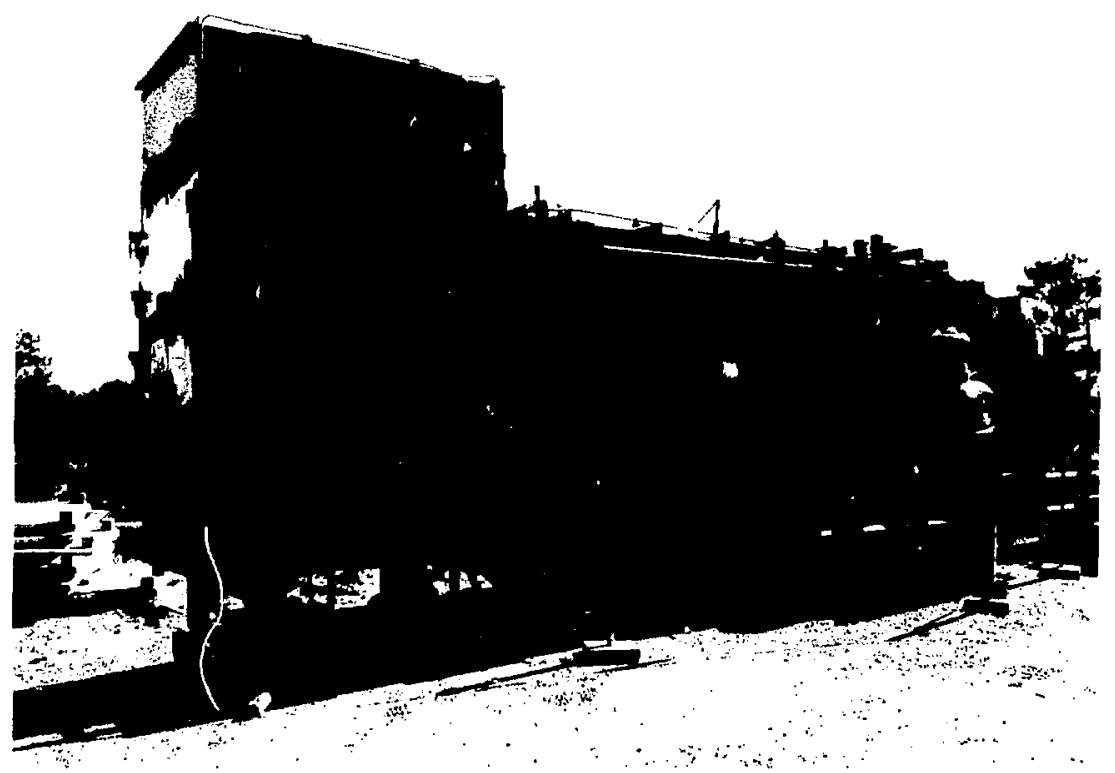

Fig. 10 .

Scrubber half, ready for loading. 


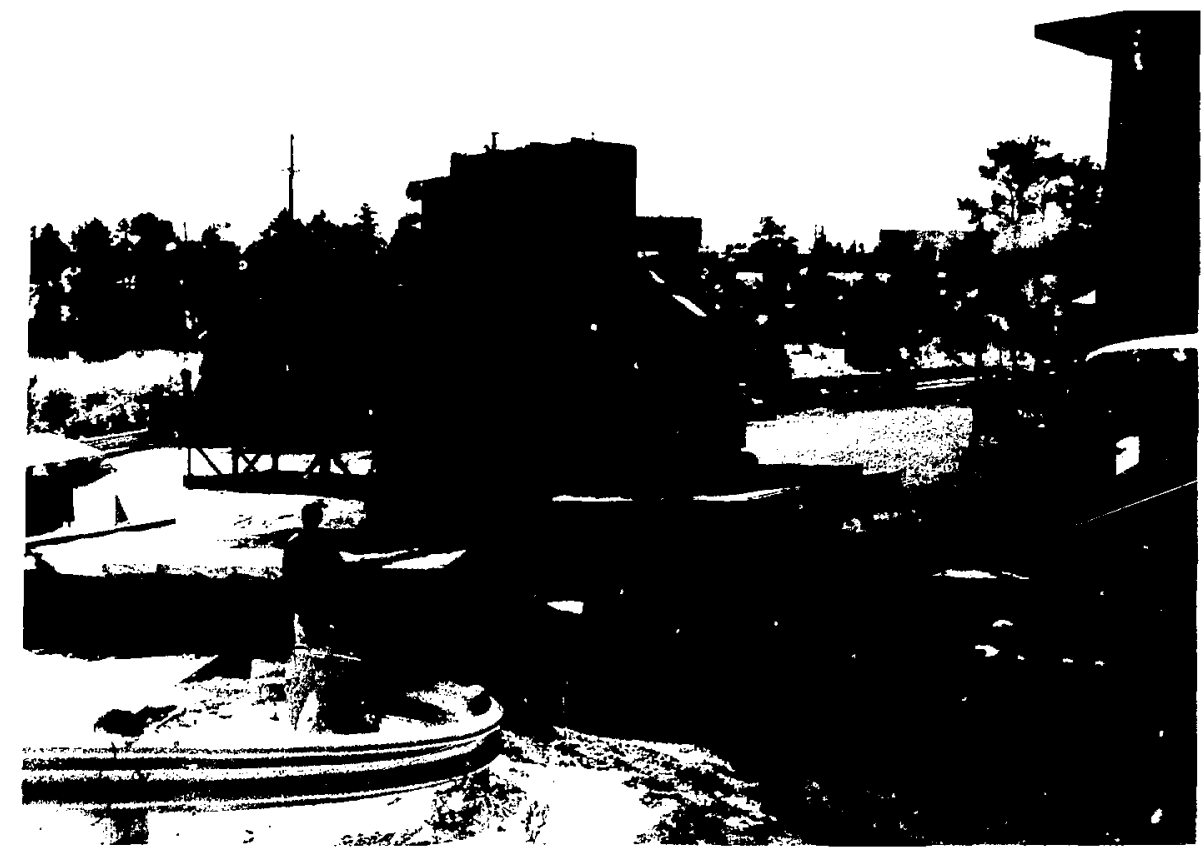

Fig. 11 .

Loading the scrubber.

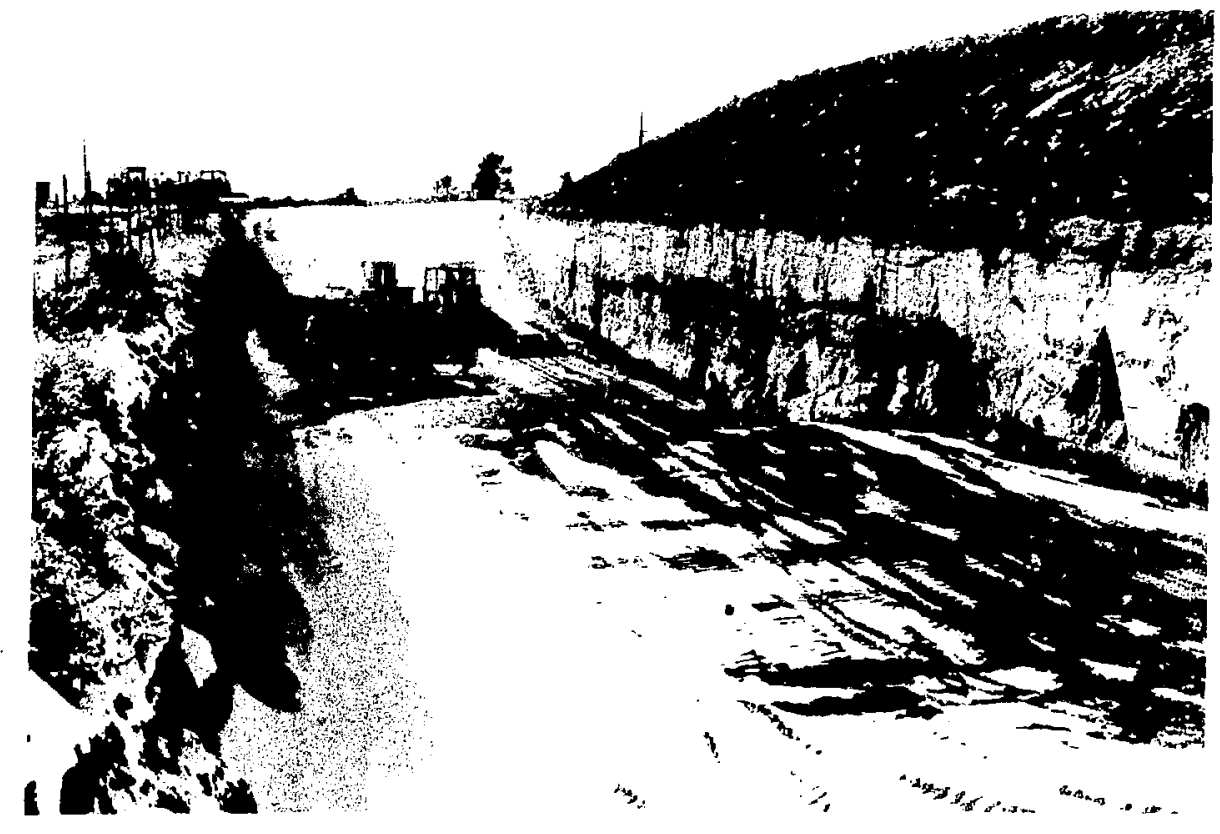

Fig. 12 .

Unloading at Waste Disposal/Storage Site. 


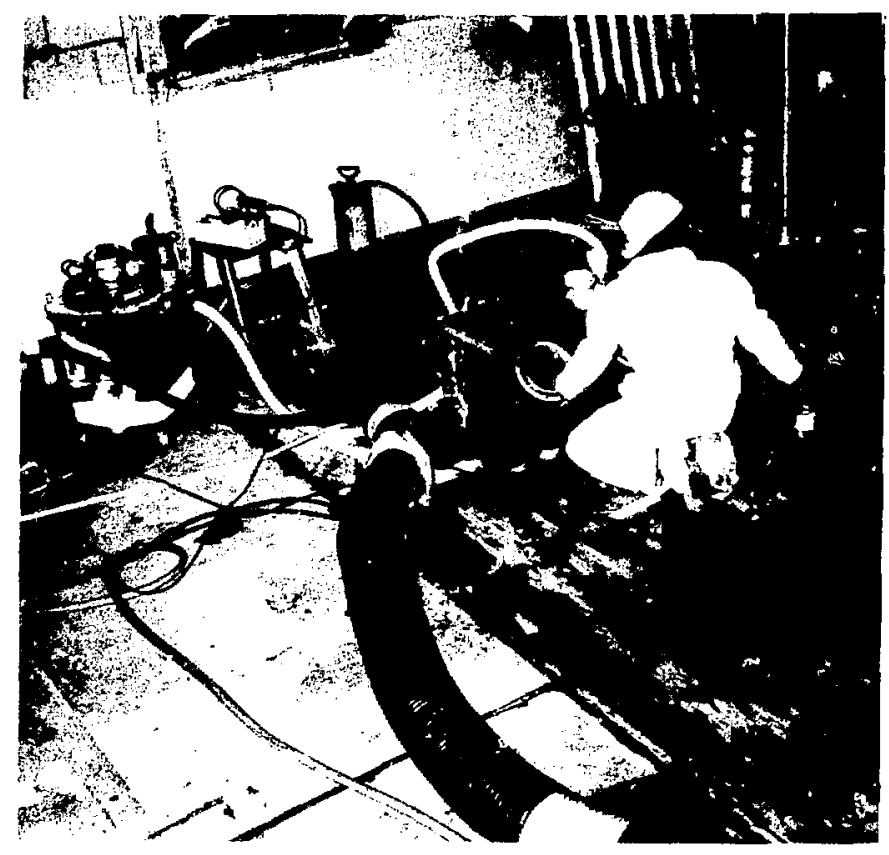

Fig. 13.

A lucite glovebox was used for dust control for concrete scarifying operations.

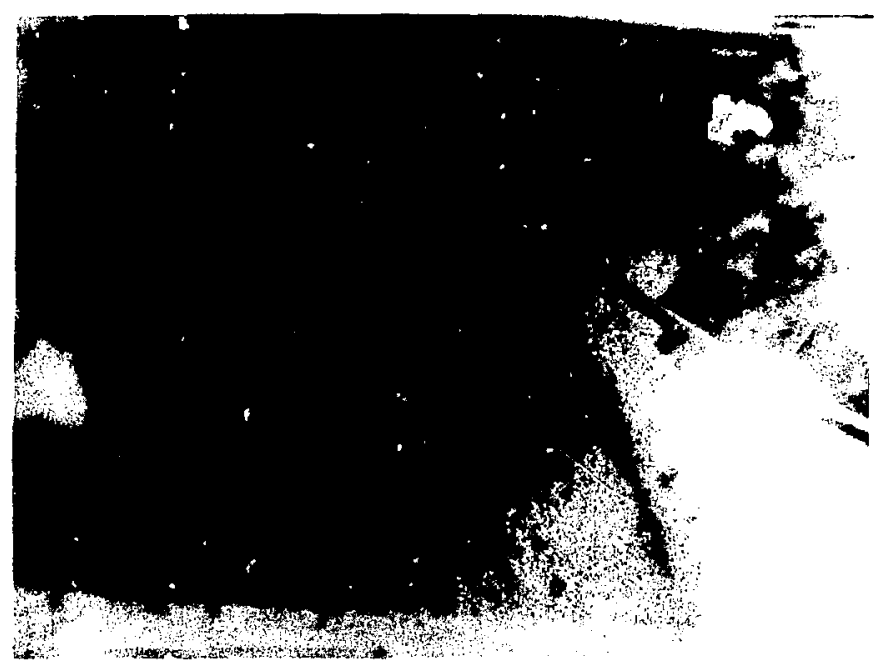

Fig. 14.

View of scarified concrete under glovebox. Glovebox had connections for air-driven scarifying tool, a vacuum for pick up of concrete chips, and its own exhaust system. 


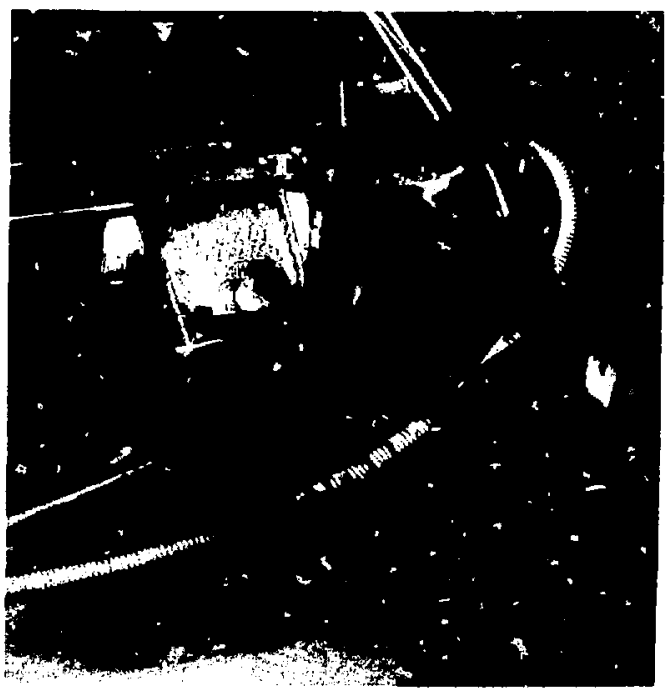

Fig. 15.

Cutting concrete to free rails.

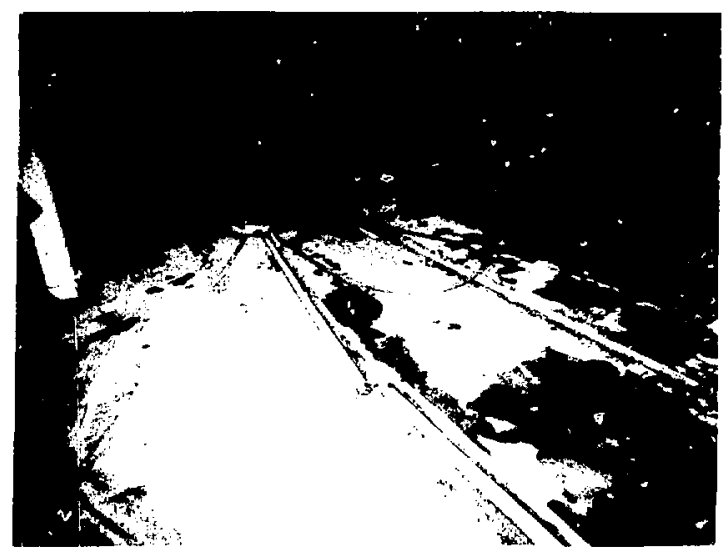

Fig. 16 .

Removing the rails.

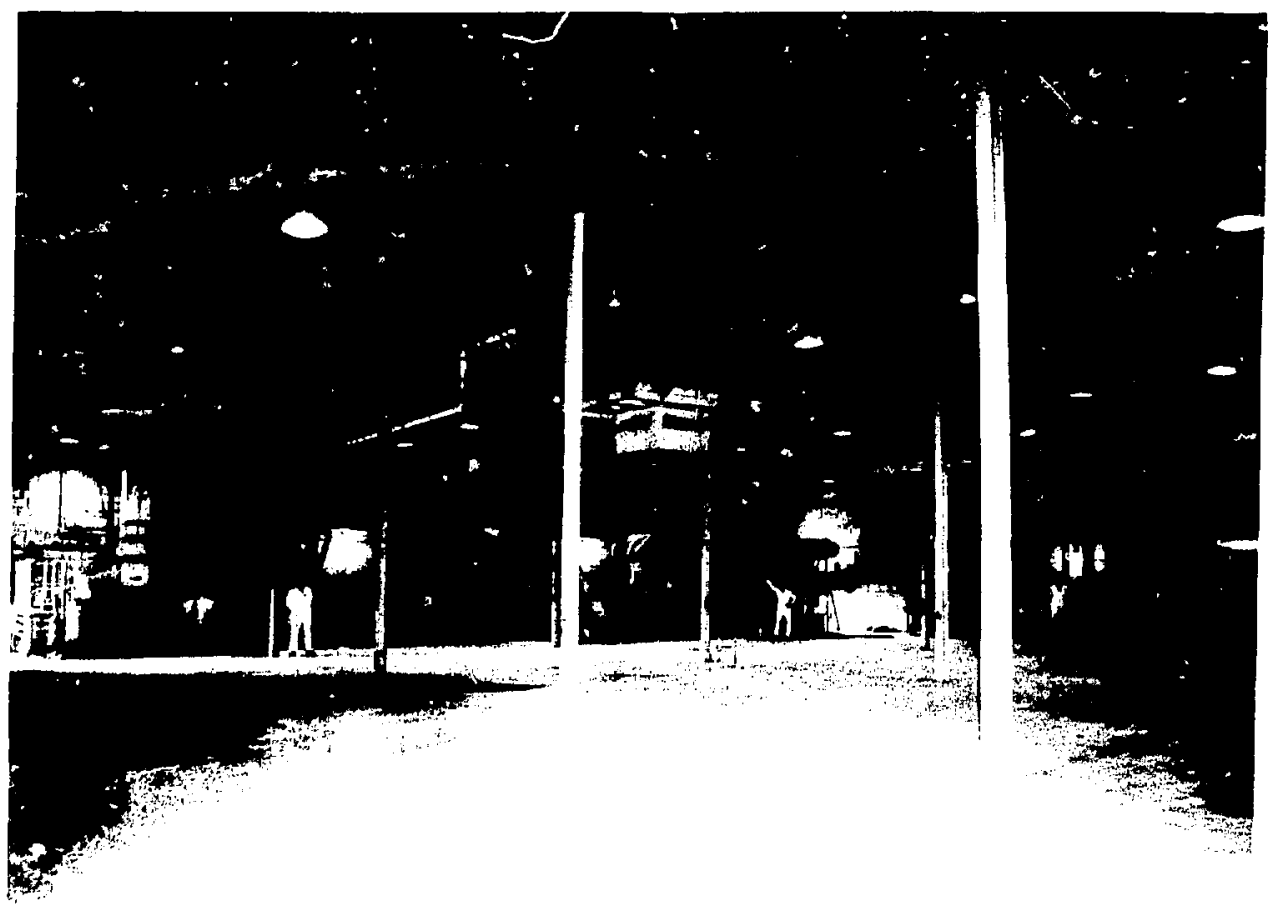

Fig. 17.

New concrete floor. 